\title{
Democratising diagnoses?: The role of the depathologisation perspective in constructing corporeal trans citizenship
}

\author{
Zowie Davy, \\ De Montfort University, UK \\ Anniken Sørlie , \\ University of Oslo, Norway \\ Amets Suess Schwend, \\ Andalusian School of Public Health, Granada, Spain
}

\begin{abstract}
In the scope of the current revision process of the diagnostic manuals Diagnostic and Statistical Manual of Mental Disorders (DSM) and International Statistical Classification of Diseases and Other Health Problems (ICD), an international trans depathologisation movement has emerged that demands, among other claims, the removal of a diagnostic classification of gender transition processes as a mental disorder. The call for submissions launched by the American Psychiatric Association (APA) and World Health Organisation (WHO) seems to provide the opportunity for a participation of civil society in the DSM and ICD revision processes. These developments open up a number of questions for us that will be discussed in this article. We conducted a meta-narrative review to explore the trans depathologisation movement's contribution to the DSM and ICD revision process, uncover evidence of a 'democratised turn' in the process, and any depathologisation proposals implemented in trans healthcare practices, human rights frameworks and legal gender recognition processes. We argue that the trans depathologisation movement have had little impact on medical practices in trans health care. However, there is some movement in local health services towards an informed consent model for limited healthcare interventions. Within some European and South / Central American legal frameworks, the depathologisation movement's demands to free legal gender recognition from medical interventions and examinations have, in different degrees, been incorporated into legal recommendations and enacted in some recent gender recognition laws.
\end{abstract}

\section{Introduction}

The revision processes of the Diagnostic and Statistical Manual of Mental Disorders Volume IV-

TR (DSM-IV-TR) and the International Statistical Classification of Diseases and Related Health

Problems Volume 10 (ICD-10) generated a broad public debate regarding trans-related diagnostic categories between academics, clinicians, and activists. The DSM is a diagnostic manual of mental 
disorders published and updated periodically by the American Psychiatric Association (APA). In spite of being developed for the US context, the DSM is known to be applied in a range of countries worldwide. Developed by the World Health Organization (WHO) and approved by the World Health Assembly, the ICD is an international diagnostic classification system applied worldwide for diagnostic and statistical purposes, as well as for regulating reimbursements. It includes both 'mental disorders' and physiological diseases alongside providing numerous codes related to other health care procedures for registering them on clinical records. Gender transition processes have been included as mental disorders in the ICD since 1975 and in the DSM since 1980. In many countries, the connection between medicine and civil status has historically been mandated in the process of legal gender recognition for trans people, by means of requiring a trans-specific diagnosis and other medical requirements (Monro and van der Ros, Monro, Takács \& Kuhar in this issue).

Over the last few years, a trans depathologisation movement has emerged with active participation of international and regional trans activism networks, groups and allies. (Suess Schwend, 2016). Trans depathologisation activism demands the de(psycho)pathologisation and removal of gender transitions as a mental disorder from both the DSM and ICD. However, the demand for depathologisation has raised concerns regarding state-funded access to healthcare, both from within the trans community and from health professionals. Therefore, the trans depathologisation movement is petitioning to attain state-funded transitioning healthcare within a human rights framework. Another request is a change in the trans healthcare model, from the current psychiatric assessment model to an informed consent approach. A further demand is the freeing of legal gender recognition from both medical interventions and diagnostic requirements. 
The depathologisation of gender diversity in childhood is also an important demand from the movement.

The depathologisation perspective draws on a human rights framework established in the Yogyakarta Principles, which are based on the application of international human rights law in relation to sexual orientation and gender identity and were developed in 2006 by an international group of experts and presented in 2007 in the UN Human Rights Council (O'Flaherty, 2015). The rights to human dignity, self-determination, bodily integrity and protection from medical abuse has achieved significant importance in the demands for the depathologisation movement and in the process of challenging the power that medical professionals hold in the distribution of citizenship rights (Suess Schwend, 2016).

The APA and WHO, in the case of the DSM and ICD respectively, said that they would include contributions not traditionally considered during the revision processes. These gestures of including research and opinions from medical stakeholders, members of trans communities, and political advocacy groups, seems to be a novel method of creating diagnoses for trans people (Davy, 2015b; Platero, 2011; Suess Schwend, 2016). Internal workgroups from the APA and WHO were tasked with developing diagnoses that reflect trans people's medical, economic and social lives. The APA working groups were established in 2008 and operated for 6 years (APA, 2013), while the WHO working groups were active from 2007 for 9 years (WHO, 2017a). The workgroups collected and exploited the evidence that they gathered in different ways. These developments opened up a number of questions for us:

1. What were the contributions and responses to the DSM and ICD revision process from the trans depathologisation movement? 
2. If and to what degree has the process of creating trans-related diagnoses in the DSM and ICD taken a democratised turn?

3. To what extent have depathologisation movement's proposals been incorporated into standards of care and trans healthcare policies?

4. In what ways have human rights frameworks and legal gender recognition been impacted by depathologisation discourses?

\section{Methodological approach}

We conducted a meta-narrative review (Gough et al., 2012), which explored the depathologisation debate and potential impact on medico-legal and policy contexts for trans people. We synthesised the findings and conclusions from existing policy documents, commentaries and declarations from academic, medical, legal and activist bodies to address the research questions (above). Because the conclusions and commentaries vary within different research paradigms, have political leanings and function within structural parameters ontologically, epistemologically, theoretically and ideologically (Gough et al., 2012), a meta-narrative review was chosen to understand the ways in which the debate about creating new trans diagnoses and medicolegal policies was understood and positionally argued from. The first analytical stage developed a disciplinary framework, upon which the authors agreed. The literature was assigned a 'disciplinary label' from the following: trans depathologisation movement and allies, medical responses, international and regional human rights discourses and domestic legal responses. From this, we developed an analysis that mapped, then reviewed the claims and declarations made by the trans depathologisation movement and their academic and medical allies and sought to analyse the inclusion of the depathologisation perspective in medical and health policy documents, and legal statutes. We did this, by drawing out if and where trans depathologisation contributions and responses were included in the 
published DSM-5 and in the ICD-11 Beta Draft, and in declarations about health service provision, international and regional human rights documents and legal statutes in a number of countries. The importance of garnering an understanding of the impact was to highlight the trans depathologisation movement's social and paradigmatic influence within the DSM and ICD revision processes, the international and regional human rights framework and medico-legal legislation in a number of countries worldwide.

We reviewed 157 documents published between 2009 and 2016 by local, regional and international activist groups and networks, among them 74 issued by regional and international activist groups and networks. Furthermore, we reviewed the following documents issued between 2009 and 2016, a selection of 150 concluding observations from UN treaty bodies, 12 resolutions from the Council of Europe Parliamentary Assembly, one issue paper from the Commissioner for Human Rights and one recommendation from the Committee of Ministers. Further, we reviewed trans people's access to legal gender recognition in 17 countries by identifying national laws that either were passed or amended between 2009 and 2016 that have clear conditions for legal gender recognition, and that do not precondition a trans-related diagnosis, hormone therapy and/or surgical interventions. Of these, we chose a sample of 10 national laws.

We start our analysis with a short contextualisation of the appearance of diagnoses in the DSM and ICD and the power that psychiatrists hold in relation to medical and healthcare for trans people. This provides the context in which the trans depathologisation movement has arisen. We will then look at some of the transformations in policy towards patient-centred medicine, which the movement is drawing on to challenge the pathologisation of trans people. We analyse the degree to which the demands of the trans depathologisation movement were considered in the DSM-5, in the ICD-11 Beta Draft, in international and regional human rights documents and in 
the legal statutes considered in this article. As a caveat, we are not testing the ways that the demands and declarations are utilised by health practitioners or how they impact those people the DSM and ICD diagnostic classifications and legal statues (will) affect, although these would be worthwhile future projects. We are providing descriptions of claims in the debate to demonstrate the use of trans depathologisation demands and declarations in institutional documents. Particularly we provide an analysis of the published discourses emerging during the revision of trans-related categories in the DSM and ICD from academic and activist perspectives. We will also explore the participation in the revision process. Furthermore, we will illustrate the level of trans depathologisation frameworks introduced in the standards of care and trans healthcare practices. To end the article we will describe the human rights discourse underpinning legal gender recognition and examine the role that trans-related diagnoses play in law in a number of countries.

\section{Politics of psychiatric diagnoses}

Prior to the 1960s, some early clinicians from private, non-academic gender clinics provided trans people transitioning surgery on demand and justified it on grounds of correcting what they considered (intersex) 'anomalies' (Stone, 1991). In the 1960s, clinicians began to refuse surgery on demand, because of the professional risks of performing experimental medicine. Clinicians started to develop criteria for approval onto gender identity programs (e.g. Benjamin, 1966). The diagnosis of transsexualism as a psychiatric 'disorder' appeared in the ICD-9 in 1975 (WHO, 1975) and in the DSM-III in 1980 (APA, 1980). There have been a number of diagnostic changes relating to trans people's gender identity issues since. Any changes in trans diagnoses have been developed by workgroups consisting of psychiatrists and sexologists appointed by the APA and WHO. Clinicians and researchers have previously said that the diagnostic changes have occurred 
because of advances in both science and culture (Levine and Solomon, 2008). While we do not have the space to consider the nuances of what psychiatric diagnoses endorse for trans people, we observe that, with the exception of a few recent changes in some countries, a psychiatric diagnosis is a prerequisite for major citizenship and healthcare rights for many trans people.

Jutel (2011) argues that diagnosis changes the practice of medicine from a purely biomedical process to a medico-social practice with intersecting social, political, technological, cultural and economic forces. According to Frank (2016), however, the diagnosis must not support any secondary gains, which is not always the case with psychiatric approaches to trans people. Secondary gains for trans people are varied, including providing referrals to surgeons for surgery, or providing evidence for amendments to the civil status of a patient's gender. In this sense, psychiatric diagnostics are personal-political-economic matters that masquerade as medical measures (Szasz, 2009).

Some recent research about psychiatric practices addresses the justice and equality issues inherent in some psychiatric practices (Kallert, 2008; Lidz et al., 2000). Psychiatry relies on 'talking' and pharmacological strategies that coerces people into acting in line with the attendant psychiatrist's standards of behaviour, while advocating what is 'normal' and 'abnormal' conduct. Trans depathologisation discourses, together with anti-psychiatric perspectives, have started to discuss how psychiatric diagnosis can be coercive, even in the face of widespread health policies shifting towards patient-centred medicine.

\section{Patient-centred health policy}

Major transformations in policy towards patient-centred medicine ${ }^{1}$ from the late 1960s (Balint, 1969), and changes in approaches from physicians and psychiatrists has resulted in a debate about 
the importance of people being at the forefront of their own healthcare. Health policy in Europe over the last ten years has acknowledged research demonstrating the benefits of shared decisionmaking, and promotion of individual and collective patient rights as dominant values and goals (Newdick and Derrett, 2006). Some research shows great gains in health outcomes and the benefits of patient-centred healthcare provision (Mead and Bower, 2000; Saha et al., 2008). However, there has been some research that shows attempts to negotiate shared decision making is sometimes fraught with difficulties from both patients' (Frosch et al., 2012) and practitioners' perspectives (Caldon et al., 2010).

The introduction of an informed consent model for hormone therapy in the US has been welcomed by many trans people and health service providers (Deutsch, 2012). Informed consent healthcare for trans people has not been widespread, and rarely extends to surgical interventions, if so desired. As such, the ways that trans people are treated, within healthcare policies and clinics, continue to be sites of activist and lay negotiations and much political, cultural, legal and scientific wrangling (Davy, 2015b; Drescher, 2013; Drescher et al., 2012; Platero, 2011, Van der Ros, 2013).

\section{Trans depathologisation movement}

Critical challenges by trans people about their healthcare have often evolved through health social movements (HSM). HSMs engage in generating research of their own, democratising the production of scientific knowledge. This research variably helps to shape health policies and influence treatments and protocols (Brown and Zavestoski, 2004). For instance, the entwined trans diagnoses, governance and citizenship rights mechanisms in social policy and legal statutes have received some international scrutiny (Cabral and Viturro, 2006; Spade, 2003; Stone, 1991; Suess Schwend, 2016; Whittle, 2002; Wilchins, 1997). Trans depathologisation discourses have emerged 
from Africa (Gunguluza, 2012), Asia (Winter, 2009; Winter et al., 2009), Latin America (Adrián, 2013; Cabral, 2010, 2014), North America (Winters, 2006, 2008, 2013) and Europe (Davy, 2011; Meyer-Bahlburg, 2010; Richardson and Monro, 2012; Suess Schwend, 2016).

Contemporary trans HSMs are divided in the ways that they should tackle policy and access to healthcare. The analysis of activist campaigns over the last few years, however, shows an increasing consensus about the removal of psychiatric diagnoses while preserving access to healthcare (Suess Schwend, 2016). Nonetheless, according to Meyer-Bahlburg (2010), Franklin Romeo of the Sylvia Rivera Law Project in New York has suggested that a DSM diagnosis is crucial in court proceedings concerning access to insurance facilitated healthcare in the US where public health care is scarce. In Romeo's view (Meyer-Bahlburg, 2010), the removal of trans diagnoses would be disastrous for US trans people. Nevertheless, the Argentinian Gender Identity Law, enacted in 2012 (see below) provides the right to legal gender recognition without medical requirements while establishing the right to state-funded trans healthcare within an informed consent model. The Argentinian law now sets a reference point for the development of other national legal frameworks and health policies that many trans activists cite as encompassing their rights for human dignity, bodily integrity and self-determination.

International trans depathologisation activism has continued to emerge, achieving a broad dissemination of their praxes in different world regions. Since 2009, STP, International Campaign Stop Trans Pathologization launches each year a Call to Action for the International Day of Action for Trans Depathologization. On this day and throughout the month of October, activist groups, organisations and networks from different world regions organise activities advocating for trans depathologisation. In October 2016, more than 120 activities took place in 47 cities worldwide. Furthermore, by June 2017 STP received endorsements from 412 activist groups and networks, 
public institutions and political organisations in Africa, Asia, Europe (including Western and Eastern Europe), Latin America, North America and Oceania. The main demands of STP are the removal of the mental disorder classification of gender transitioning processes from the DSM and ICD, the right to the provision of state-funded trans healthcare, changes to existing trans healthcare models, legal gender recognition without medical requirements, depathologisation of gender diversity in childhood, and protection against discrimination and transphobia. In order to facilitate state-funded trans healthcare provision, STP proposes: 1. The elaboration of a human rights-based framework for trans healthcare, 2. The introduction of a non-pathologising code in the ICD, as a health process not based on disorder or disease, and 3. The elaboration of context-specific strategies (Suess Schwend, 2016). ${ }^{2}$

International activist networks have published declarations supporting the demand for trans depsychopathologisation $^{3}$ and many local activist groups have launched similar declarations (Suess Schwend, 2016). Trans academics, many of whom are activists, have recently contributed to the debate about trans depathologisation (Cabral, 2010, 2014; Davy, 2015b; Gunguluza, 2012; Missé and Coll-Planas, 2010a, 2010b; Platero, 2014; Suess, 2010; Suess Schwend, 2016; Suess et al., 2014; Thomas et al., 2013; Winter, 2014, 2015; Winter et al., 2009; Winters, 2008, 2013, 2014). This debate has built on trans activism that emerged a few decades ago (e.g. Burns, 2005; Spade, 2003; Stone, 1991; Stryker, 1994; Wilchins, 1997; Wilson, 1997, 2010; Winters, 2006; for activist actions see Suess Schwend, 2016). Apart from publishing declarations, activist groups and networks participated in the Call for Proposals launched by the APA by sending reviews of the trans-related diagnostic categories published on the DSM-5 Draft website, including proposals for their reform or removal. After the publication of the DSM-5 (APA, 2013), STP criticised the continued classifications Gender Dysphoria in Adolescents and Adults, Gender Dysphoria in 
Children and Transvestic Disorder (APA, 2013), demanding the complete removal of trans-related categories from DSM-5.

In 2011, the WHO called for proposals on the revision process of trans-related categories in the ICD (Drescher et al., 2012). Among the received proposals, listed in Drescher, et al. (2012) was a report developed by Global Action for Trans Equality (GATE), which summarises the results of an International Expert Meeting that congregated in The Hague in November 2011. In the meeting, a proposal for non-pathologising trans-related codes in ICD-11 were elaborated on, in order to facilitate access to state-funded trans healthcare. In 2013, GATE organised a second meeting in Buenos Aires, and focused on developing arguments for the removal of the diagnostic classification of gender diversity in childhood from the ICD. Furthermore, the meeting produced an alternative proposal for the ICD-11 based on codes listed in ICD-10 Chapter XXI, Factors influencing health status and contact with health services, with the aim of facilitating access to psychosocial support for those gender diverse children and their families who require it.

Over the last two years, several international and regional trans activist networks have published statements demanding the removal of a diagnostic classification of gender diversity in childhood. By June 2017, 231 health professionals and researchers from different world regions signed a statement supporting this demand (Winter et al., 2016). Trans authors and allies have questioned the maintenance of diagnostic categories for pre-adolescent children (Adams, 2014; Cabral, et al. 2016; Suess Schwend, 2016, 2017; Winter, 2014, 2015; Winter, Diamond, et al. 2016; Winter, Ehrensaft, et al. 2016; Winter, Riley, et al. 2016; Winters, 2013, 2014). This questioning is based on earlier critiques of the diagnostic classification of gender diversity in childhood (Bartlett et al., 2000; Langer and Martin, 2004). Furthermore, several activist groups 
and networks have demanded the publication of the WHO workgroup proposal so that trans activists can make a formal critique of it.

After the proposal of the Working Group on the Classification of Sexual Disorders and Sexual Health being published in the ICD-11 Beta Draft in August 2014 (WHO, 2017b), several activist networks launched press releases, praising the removal of trans related categories from the chapter Mental and Behavioural Disorders. The networks also agreed with the inclusion of a transspecific category for adolescents and adults in the proposed chapter Conditions related to sexual health (WHO, 2017b), while criticising the continued classification of gender diversity in childhood and the concept "gender incongruence."

Trans depathologisation activism has also demanded a change in healthcare provision by suggesting replacing any system using psychiatric assessments as a precursor to the provision of hormone treatments and trans-related surgeries with an informed consent approach. The informed consent model focuses on information and counselling and recognises trans people's right to bodily autonomy and informed decision making (Suess Schwend, 2016). During the revision process of the $6^{\text {th }}$ version of the Standards of Care (SOC-6), published by the Harry Benjamin International Gender Dysphoria Association (HBIGDA) in 2001 (now World Professional Association for Transgender Health (WPATH)), activist groups and networks worldwide provided alternative proposals, based on a depathologisation framework, taking into account some culturally specific aspects of trans people's lives. After the publication of SOC-7 in 2012 (WPATH, 2012), several activist networks published their reviews of the new edition. The networks acknowledged that there had been some improvements: the conceptualisation of gender transitions as nonpathological, the challenging of non-discriminatory language, the inclusion of a broad diversity of gender expressions, transitioning trajectories and gender identities, the need for flexibility in trans 
healthcare pathways, the explicit condemnation of reparative therapies, and the recognition of the cultural diversity of trans people. Simultaneously, the activist networks criticised the use of a pathologising diagnostic framework, the continuation of an assessment model, including the requirement of " 12 continuous months of living in a gender role that is congruent with [trans people's] gender identity" (WPATH, 2012: 60, 106), and the pathologising terminology used in the chapter on intersex.

In relation to legal gender recognition, the trans depathologisation movement demands that future gender identity laws be without medical requirements and restrictions related to the civil status, such as having to be divorced if married, age or nationality. Furthermore, they insist that governments remove such requirements from existing gender identity laws (Suess Schwend, 2016). Viewed as forms of medical abuse and coercion by activists, the compulsory legal requirements of diagnosis, hormone treatment, sterilisation, genital surgery or divorce constitute human rights violations and are an obstruction to the right to bodily integrity and right to a family life. Moreover, medical requirements are contrary to the rights established in the Universal Declaration of Human Rights, and Yogyakarta Principles. Trans depathologisation activist groups and networks have celebrated the Argentinian Gender Identity Law, and legal gender recognition advancements, such as the approval of gender identity laws without medical requirements in Denmark, Malta, Colombia, México D.F., Ireland and Norway, the removal of the sterilisation requirement in Sweden, as well as other law proposals, such as in Chile. Simultaneously, activists continue to denounce any legal criminalisation and persecution, social and labour exclusion and transphobic violence. This leads us to a discussion about the level of impact that depathologisation discourses have had within the human rights framework and legal gender recognition processes. 


\section{Depathologisation as a human rights issue}

The rights of trans people regarding legal gender recognition and access to trans health care have gathered momentum under the case law of the European Court of Human Rights (ECtHR). The court's interpretation of article 8 of the European Convention on Human Rights (ECHR) ensures the right to respect for a private life (Christine Goodwin v. the United Kingdom; van Kück v. Germany). Pathologisation of transsexuality has had limited discussion against the backdrop of international human rights law. Yet, depathologisation can be addressed under article 8 detailing the right to a private life in the ECHR and in article 17 of the International Covenant on Civil and Political Rights. Gender identity is one of the most intimate aspects of a person's life, which falls within the ambit of article 8 (Goodwin). Article 8 protects the right to personal development, to establish details of one's identity, and the physical and psychological integrity of a person (Goodwin; van Kück). To be labelled as mentally ill encroaches on the integrity of people and cannot be justified under article 8 (2). Depathologisation falls also under the right to health (article 12) and non-discrimination (article 2(2)) under the International Covenant on Economic, Social and Cultural Rights (ICESCR), particularly because of the stigma attached to pathologisation and how being labelled as mentally ill affects the health of trans people (Theilen, 2014). The pathologising of trans people and not cis people cannot be justified, according to Theilen (2014), and amounts to discrimination. An increased body of soft law supports these views, such as the Yogyakarta Principles.

The Yogyakarta Principles are not legally binding, but the Principles have attained wide international recognition as "an important tool in identifying the obligations of states to respect, protect and fulfil the human rights of all persons, regardless of their sexual orientation or gender 
identity" (Hammarberg cited in O'Flaherty, 2015: 291). Of interest to this article, is Principle 18, which declares:

Notwithstanding any classifications to the contrary, a person's sexual orientation and gender identity are not, in and of themselves, medical conditions and are not to be treated, cured or suppressed.

When addressing medical requirements for legal gender recognition, human rights mechanisms are increasingly pursuing this view, as well as urging states to abolish trans-related diagnosis as a precondition for legal gender recognition and to ensure access to trans-specific healthcare without requiring a mental illness in line with the demands of the depathologisation movement. For example, in its 2011 Concluding Observation to Germany, the Committee on Economic, Social and Cultural Rights stated:

The Committee notes with concern that transsexual and inter-sexed persons are often assimilated to persons with mental illness and that the state party's policies, legislative or otherwise, have led to discrimination against these persons as well as to violations of their sexual and reproductive health rights (arts. 12, 2.2).

Yet, in the 150 concluding observations reviewed, UN treaty bodies only address medical requirements for legal gender recognition and/or access to trans-specific healthcare in four of the concluding observations. Sexual orientation and/or gender identity are mentioned in 63 concluding observations, and particularly in relation to protection against discrimination.

In 2009, in the issue paper Human Rights and Gender Identity, the former Commissioner for Human Rights Thomas Hammarberg (2009: 25) emphasised that "[f]rom a human rights and health care perspective no mental disorder needs to be diagnosed in order to give access to treatment for a condition in need of medical care." Further, in five out of 12 Council of Europe 
Parliamentary Assembly (PACE) resolutions that include trans people or gender identity, explicit reference to medical requirements for legal gender recognition and access to trans-specific healthcare was made. In 2015, for example, PACE expressed its concern about the human rights violations trans people face when seeking legal gender recognition that requires inter alia sterilisation and a diagnosis of mental illness. PACE (2015) and the Council of Europe Committee of Ministers (2010) call on European member states to abolish sterilisation, compulsory medical treatments, and a mental health diagnosis to gain legal gender recognition, while ensuring access to and reimbursement by public health insurance schemes for gender reassignment procedures. While human rights mechanisms have primarily been focusing on sterilisation, depathologisation and access to state-funded healthcare are increasingly gaining attention as a human rights issue.

\section{National law reforms on legal gender recognition}

The demands of the depathologisation movement to 1) free legal gender recognition from medical interventions, such as genital surgery or sterilisation, 2) to detach legal gender recognition from any medical requirements, including surgical interventions, medical examinations and diagnoses, and 3) to ensure state-funded transitioning healthcare, will facilitate a complete distinction between medicine and legal gender recognition. Recent national legal gender recognition laws have responded to these demands in varying ways.

Before the establishment of an international depathologisation movement, local groups worked actively in freeing legal gender recognition from medical requirements. As a result, in the UK (2004) and Spain (2007) laws they did not require surgical interventions. However, the British Gender Recognition Act requires a diagnosis of either gender dysphoria or evidence of surgical interventions, whereas the Spanish gender identity law requires gender dysphoria and two years of 
medical treatment, usually hormone treatment. From 2009 to 2016, national legislative bodies in different countries enacted laws that freed legal gender recognition from more medical requirements.

The depathologisation movement demands that legal gender recognition shall be detached from medical interventions. The 2011 Portuguese gender identity law requires the applicant to be diagnosed with gender identity disorder and be over 18 years (article 2). A diagnosis must appear in a report prepared by a multidisciplinary clinical sexology team (article 3 (1) b). The registrar shall decide on the request for change of legal gender within eight days (article 4). Contrary to the Swedish act (see below), the act explicitly requires the diagnosis of gender dysphoria.

In 2013, the 1972 Swedish Act legally recognising trans people was amended and the infertility/sterilisation requirement repealed. Contrary to the acts mentioned above, the requirement of a diagnosis or medical examination follows from an interpretation of the wording of the law, which shows similarities with the definition of the diagnosis of gender dysphoria (SOU 2014: 91 para 7.9.1) and from medical recommendations. Common for these laws is that they comply with the demand of freeing legal gender recognition from requirements of sterilisation or infertility. However, legal gender recognition requires medical examinations or a diagnosis.

Contrary to the laws mentioned above, the Argentine Gender Identity Act (2012), the Danish Act on the Civil Registration System (as amended 2014), the Maltese Gender Identity, Gender Expression, and Sex Characteristics Act (2015), the Columbian Gender Recognition Act (2015), the Civil Code of Mexico City (as amended 2015), the Irish Gender Recognition Act (2015), the French Gender Identity Act (2016), and the Norwegian Act on Change of Legal Gender (2016) all detach legal gender recognition from medical interventions for people above 18 years. In 2012, the Argentine Senate enacted the Law 26.743, including a regulation for the right to 
gender identity and comprehensive state-funded healthcare for trans people. The act introduced an unprecedented law for trans people based on human rights principles. No medical diagnosis or treatment is required for a change of legal gender and it allows children to consent to change their legal gender when supported by their legal representatives.

Similarly, the Maltese Gender Identity, Gender Expression, and Sex Characteristics Act adopted 2015, complies with most of the demands of the depathologisation movement. The Act explicitly ensures the right of all Maltese citizens to recognition of their gender identity (Section 3 ), and a correction of the recorded gender without any requirements of diagnosis or medical treatment (Section 4). Any change of a recorded gender is self-declarative. Additionally, the act enshrines the bodily integrity and physical autonomy of minors when outlawing sex assignment treatment and/or surgical intervention on the sex characteristics of a minor (Section 14 (1)). By way of an amendment to the act in 2016, pathologisation of any form of gender identity or gender expression as classified under the ICD or any other similar internationally recognised classification is invalid in Malta (Section 15 (2)). Further, the Affirmation of Sexual Orientation, Gender Identity and Gender Expression Act enacted in 2016, prohibits pathologisation of any gender identity or gender expression. However, trans-specific state-funded healthcare is not ensured under the law.

The French act frees legal gender recognition from medical interventions and examinations, but requires a court procedure rather than self-declaration of gender. The Norwegian act provides change of legal gender based on self-declaration from the age of 16 . For children between the age of 6 and 16, change of legal gender requires, as a main rule, consent from those with the parental responsibility, but no diagnosis or medical examination is required. However, for children below 6 years, the act introduces a diagnostic requirement where healthcare professionals must document that they have "a congenital somatic sex development uncertainty" for the 
correction of legal gender to be granted. Further, the act does not ensure a right to state-funded trans-specific healthcare (Sections 2, 4 and 5; Monro and van der Ros, in this journal; Sørlie, 2016). Thus, the Act does only partially meet the demands of the depathologisation movement. Under the Irish Act, people over the age of 18 years can self-declare their gender (Section 9). For children who have attained the age of 16 years but not 18 years, however, a certification from two medical practitioners, parental consent and court order are required (Section 12). The act does not allow children below the age of 16 years to obtain legal gender recognition. Neither the Irish act nor the Norwegian act does cut off the ties to the medical profession completely.

A lack of available trans-specific healthcare may negatively affect the health of trans people and their right to respect for their private life sanctioned under Article 8 of the ECHR and the right to health under article 12 of the ICESCR, as demonstrated above. Yet, of the gender recognition acts enacted or amended between 2009 and 2016, it is only the Argentine gender recognition law that ensures access to trans-specific healthcare. Article 11 of the Act approves a self-determined right to "total and partial surgical interventions and/or comprehensive hormonal treatment to adjust their bodies" (cited in Dunne et al., 2015: 580).

The developments in some national legislation law reforms follow the Argentine example by casting aside medical interventions, medical examinations and trans-related diagnoses. Yet, in most countries, there is still a need for much improvement of national gender recognition laws to meet the demands of the depathologisation movement. Particularly, this concerns those countries in which gender recognition laws require sterilisation and genital surgery, but also those countries in which diagnosis is maintained in, for example, England, Spain and Portugal alongside more recent legislation, such as the Irish, French and Norwegian gender recognition acts. According to TGEU and Balzer (2016a, 2016b), in 29 of 62 mapped countries / territories worldwide in which 
legal change of gender is possible, sterilisation and/or genital surgery are still required for a change of the gender marker, and in 54 of the 62 countries / territories, a diagnosis requirement is maintained.

\section{Summary and conclusion}

The first question we raised at the start of this article was about the contribution of the depathologisation movement to the revision process of trans-related diagnoses in DSM and ICD. Some trans people have concerns about removing the diagnostic classification of gender transition processes, based on the fear of losing access to state-funded trans healthcare (García Becerra and Missé, 2010; Missé and Coll-Planas, 2010b). Trans depathologisation activism has responded to this concern by developing arguments based on a human rights framework (Suess Schwend, 2016).

During the DSM and ICD revision processes, trans depathologisation groups and networks demanded a higher level of participation, however, we observed in relation to our second question about the democratisation of diagnosis that the opportunities for trans activists' and networks' to participate were curtailed within the consultation process. Trans authors and allies have been able to contribute critiques on the participation process and the proposed and final content, but have no guarantees that their critiques were heard or taken into consideration. Stakeholders were also unable to take part in the final decision making processes. Activists have also illustrated that there are tensions between challenging the diagnostic framework while participating in its reform, and managing the fear of reduced activist impact in the negotiation process (Fernández, 2010; Missé, 2012). As such, a "democratisation of diagnosing" (Davy, 2015a) seems to be still incipient.

Trans depathologisation activism criticises the maintenance of an assessment model in the most recent edition of the Standards of Care SOC-7 (WPATH, 2012), as well as in trans healthcare 
practice. Activists are proposing the use of an informed consent approach and convincingly highlight its relation to patient-centred healthcare and shared decision-making models, which are increasingly being applied in wider healthcare settings (Balint, 1969; Mead and Bower, 2000; Newdick and Derrett, 2006; Saha et al., 2008). However, these proposals have had little impact on medical practices in trans health care. Nonetheless, there is some movement in health services. For instance, there are a few trans health care centres in the US that use an informed consent model for access to hormone therapy (Callen Lorde Community Health Center, 2014; Radix, 2011; Tom Waddell Health Center, 2011). Also, there is a guarantee in the Argentinian Gender Identity Law of an informed consent approach for state-funded trans health care (Congreso Argentino, 2012), and there are trans health care services based on informed decision making in the public health care system of Andalusia, Spain (Junta de Andalucía, 2017a, 2017b).

In relation to the ways that human rights frameworks and legal gender recognition has been impacted by depathologisation discourses, we have demonstrated that the human rights principles of human dignity, bodily integrity, self-determination and protection from medical abuse are significant in trans depathologisation activism as reference points, and as part of an argumentation strategy. At the same time, recent strategic documents published by European political and legal institutions have recommended the removal of the diagnostic classification of gender transition processes in the ICD, integrating the demand of depathologisation in their agenda (Suess Schwend, 2016).

We note that in many countries worldwide trans people still lack opportunities for legal gender recognition. In achieving legal recognition of their gender identity, some trans people's human rights are violated through processes of coercive diagnosing and sterilisation. In countries like Spain, the United Kingdom and Portugal the requirement of a trans-related diagnosis continues 
to be coupled with legal gender recognition. According to Sharpe (2010), British legislation presupposes body modification even though no surgical or hormonal requirements were written into law. This is so, Sharpe argues, because trans people must exhibit gender dysphoria, which is usually understood as distress about 'sex' characteristics. Consequently, legal requirements based upon trans-related diagnoses pose a risk of reintroducing surgical and hormonal practices through the back door. Moreover, these diagnoses act as gatekeeper to other healthcare services and citizenship rights. This then constitutes a coercive relationship by offering something positive healthcare and legal recognition - in exchange for compliance with psychiatry. The Argentinian Gender Identity Law, however, is exemplary at guaranteeing trans rights - both legal recognition and healthcare access - within a human rights framework, setting a reference point for recent law reforms, as well as for the ICD revision process. Trans movement participation should be encouraged in the processes of guaranteeing human rights for trans people.

\section{Notes}

1 Recently, the term "person-centred healthcare" or "people-centred healthcare" is given preference over "patient-centred" and are considered more inclusive, empowering and focused on the person's and community's needs (WHO-WPRO, 2016).

${ }^{2}$ A list of activist documents published between 2009 - 2015 can be found in Suess Schwend (2016). Declarations published between January 2016 and June 2017 are available on the websites of APTN, Asia Pacific Network; GATE, Global Action for Trans Equality; ILGAWorld; Iranti.org; STP, International Campaign Stop Trans Pathologization and TGEU, Transgender Europe.

${ }^{3}$ Depsychopathologisation is a demand shared by all activist groups in relation to changes in transrelated diagnostic categories. Simultaneously, there are different proposals regarding the inclusion 
of an alternative diagnostic category in ICD that will ensure public coverage of trans healthcare, resulting in different levels of "depathologisation" claims.

\section{References}

Adams K (2014) There is truly nothing wrong with these children. Available at:

https://gidreform.wordpress.com/2014/07/24/there-is-truly-nothing-wrong-with-thesechildren/ (accessed 8 February 2016).

Adrián T (2013) Cuadrando el círculo: despatologización vs derecho a la salud de personas trans en DSM-5 y CIE-11. Comunidad y Salud 11(1): 60-67.

APA (1980) Diagnostic and Statistical Manual of Mental

Disorders: (DSM III). Washington: American Psychiatric Association.

APA (2013) Diagnostic and Statistical Manual of Mental

Disorders: DSM 5. Washington: American Psychiatric Publishing.

Balint E (1969) The possibilities of patient-centered medicine. British Journal of General Practice 17(82): 269-276.

Bartlett NH, Vasey PL and Bukowski WM (2000) Is gender identity disorder in children a mental disorder? Sex Roles 43(11-12): 753-785.

Benjamin H (1966) The Transsexual Phenomenon. New York: Julian Press.

Brown P and Zavestoski S (2004) Social movements in health: An introduction. Sociology of Health \& Illness 26(6): 679-694.

Burns C (2005) A basis for evaluating care approaches and services for trans people in the $U K$. Available at: www.changelingaspects.com/PDF/cb-eval1.pdf (accessed 8 February 2016).

Cabral M (2010) Autodeterminación y libertad. Available at: www.pagina12.com.ar/diario/suplementos/soy/1-1675-2010-10-22.html (accessed 8 February 2016)

Cabral M (2014) Leyendo entre líneas. Día de acción mundial por la despatologización trans. Available at: www.pagina12.com.ar/diario/suplementos/soy/1-3667-2014-10-17.html (accessed 8 February 2016).

Cabral M and Viturro P (2006) (Trans)sexual citizenship in contemporary Argentina In:

Currah P, Juang RM and Minter PS (eds) Transgender Rights. Minneapolis: University of Minnesota Press, pp.262-273. 
Cabral M, Suess A, Ehrt J, Seehole TJ and Wong J (2016) Removal of a gender incongruence of childhood diagnostic category: a human rights perspective. Lancet Psychiatry 2016;3(5):405-406.

Caldon L, Collins K, Reed M, et al. (2010) Clinicians' concerns about decision support interventions for patients facing breast cancer surgery options: understanding the challenge of implementing shared decision-making. Health Expectations 14(2): 133-146.

Callen Lorde Community Health Center (2014) Callen Lorde's Hormone Therapy Protocols (2014 Revision). Available at: https://issuu.com/callenlorde/docs/tg_protocols_2014_v.5 (accessed 18 March 2017).

Christine Goodwin v. the United Kingdom [GC], no. 28957/95, ECHR 2002-VI.

Congreso Argentino (2012) Identidad de Género. Ley 26.743. Boletín Oficial de la República Argentina $N^{o} 32.404,24$ de mayo de 2012. Available at: http://www4.hcdn.gov.ar/BO/boletin12/2012-05/BO24-05-2012leg.pdf (accessed 18 March 2017). English translation by GATE, Global Action for Trans Equality (2012) available at: http://transactivists.org/wp-content/uploads/2012/05/argentina-genderidentity-law.pdf (accessed 18 March 2017).

Council of Europe (2010) Recommendation of the Committee of Ministers on measures to combat discrimination on grounds of sexual orientation or gender identity. Committee of Ministers, Strasbourg, 31 March.

Davy Z (2011) Recognizing Transsexuals: Personal, Political and Medicolegal

Embodiment, Aldershot: Ashgate.

Davy Z (2015a) Democratizing diagnoses: (Trans*)forming the DSM 5. In: European

Professional Association of Transgender Health, Transgender health care in Europe. University of Ghent, Belgium, 12-14 March.

Davy Z (2015b) The DSM-5 and the politics of diagnosing transpeople. Archives of Sexual Behavior 44(5): 1165-1176.

Degner A and Nomanni M (2015) Psychiatry in legal gender recognition procedures in Europe. In: Jubiläumsfeier, 5 Jahre Humboldt Law Clinic, Grund und Menschenrechte, Berlin, Germany, 27 November.

Deutsch MB (2012) Use of the informed consent model in the provision of cross-sex hormone therapy: A survey of the practices of selected clinics. International Journal of Transgenderism 13(3): 140-146.

Drescher J (2013) Controversies in gender diagnoses. LGBT Health 1(1): 10-14.

Drescher J, Cohen-Kettenis P and Winter S (2012) Minding the body: Situating gender identity diagnoses in the ICD-11. International Review of Psychiatry 24(6): 568-577.

Fernández S (2010) Derechos sanitarios desde el reconocimiento de la diversidad. Alternativas a 
la violencia de la psiquiatrización de las identidades trans. In: Missé M and Coll-Planas G (eds) El Género Desordenado. Críticas en Torno a la Patologización de la

Transexualidad. Barcelona: Egales, pp.177-198.

Frank AW (2016) From sick role to narrative subject: An analytic memoir. Health 20(1): 9-21.

Frosch DL, May SG, Rendle K, et al. (2012) Authoritarian physicians and patients' fear of being labeled "difficult" among key obstacles to shared decision making. Health Affairs 31(5): 1030-1038.

García Becerra A and Missé M (2010) Diálogo trans-cultural. In: Missé M and Coll-Planas G (eds) El género desordenado. Críticas en torno a la patologización de la transexualidad. Barcelona: Egales, pp.197-204.

Gough D, Thomas J and Oliver S. (2012) Clarifying differences between review designs and methods. Systematic Reviews 1: 1-9.

Gunguluza N (2012) Report of the Gender DynamiX trans health \& advocacy conference

2011. Retrieved from www.genderdynamix.org.za/wp-content/uploads/2012/11/TransHealth-Advocacy-Conference-2011-report.pdf (accessed 1 February 2016).

Hammarberg T (2009) Human rights and gender identity. Issue paper for the Office of the Commissioner for Human Rights, Council of Europe, July.

HBIGDA (2001) The Harry Benjamin International Gender Dysphoria Association's Standards

of Care for Gender Identity Disorders, Sixth Version. Retrieved from Www.transgendercare.com/guidance/resources/hbigda01/ (accessed 9 February 2016).

Junta de Andalucía (2017a) PAI, Proceso Asistencial Integrado Atención sanitaria a personas transexuales adultas. Available at: http://www.juntadeandalucia.es/salud/sites/csalud/contenidos/Informacion_General/p_ 3_p_3_procesos_asistenciales_integrados/pai/transexuales_adultos?perfil=org (accessed 18 March 2017).

Junta de Andalucía (2017b). PAI, Proceso Asistencial Integrado Atención sanitaria a personas t ransexuales en la infancia y adolescencia. Available at: http://www.juntadeandalucia.es/salud/sites/csalud/contenidos/Informacion_General/p_ 3_p_3_procesos_asistenciales_integrados/pai/transexuales_infancia_adolescencia?perfil= org (accessed 18 March 2017).

Jutel A (2011) Putting a name to it: Diagnosis in contemporary society, Baltimore: John Hopkins University Press.

Kallert TW (2008) Coercion in psychiatry. Current Opinion in Psychiatry 21(5): 485-489.

Langer S and Martin JI (2004) How dresses can make you mentally ill: Examining gender identity disorder in children. Child and Adolescent Social Work Journal 21(1): 5-23.

Levine SB and Solomon A (2008) Meanings and political implications of "psychopathology" in 
a gender identity clinic: A report of 10 cases. Journal of Sex \& Marital Therapy 35(1): 40-57.

Lidz CW, Mulvey EP, Hoge SK, et al. (2000) Sources of coercive behaviours in psychiatric admissions. Acta Psychiatrica Scandinavica 101(1): 73-79.

Mead N and Bower P (2000) Patient-centredness: A conceptual framework and review of the empirical literature. Social Science \& Medicine 51(7): 1087-1110.

Meyer-Bahlburg HFL (2010) From mental disorder to iatrogenic hypogonadism: Dilemmas in conceptualizing gender identity variants as psychiatric conditions. Archives of Sexual Behavior 39(2): 461-476.

Missé M (2012) La lucha por la despatologización trans y perspectivas de futuro del movimiento trans en Barcelona. Available at: http://fundacionbetiko.org/wpcontent/uploads/2012/11/La-lucha-por-la-despatologizaci\%C3\%B3n-trans-yperspectivas-de-futuro-del-movimiento-trans-en-Barcelona.pdf (accessed 8 February 2016)

Missé M and Coll-Planas G (eds). (2010a) El género desordenado. Críticas en torno a la patologización de la transexualidad. Barcelona: Egales.

Missé M and Coll-Planas G (2010b) La patologización y propuestas de la transexualidad: Reflexiones críticas. Norte de Salud mental 8(38): 44-55.

Monro S and Warren L (2004) Transgendering citizenship. Sexualities 7(3): 345-362.

Newdick C and Derrett S (2006) Access, equity and the role of rights in health care. Health Care Analysis 14(3): 157-168.

O'Flaherty M. (2015) The Yogyakarta Principles at ten. Nordic Journal of Human Rights 33(4): 280-298.

PACE (2015) Discrimination against transgender people in Europe 15th sitting, resolution 2048.

Platero R(L) (2011) The narratives of transgender rights mobilization in Spain. Sexualities 14(5): 597-614.

Platero R(L) (2014) The influence of psychiatric and legal discourses on parents of gendernonconforming children and trans youths in Spain. Journal of GLBT Family Studies 10(1-2): 145-167.

Radix A (2011) New Horizons in Transgender Health. In: Gunguluza N (ed) Report of the Gender DynamiX Trans Health \& Advocacy Conference. Cape Town: Gender DynamiX, pp. 8-9. Available at: http://www.genderdynamix.org.za/wpcontent/uploads/2012/11/Trans-Health-Advocacy-Conference-2011-report.pdf (accessed 18 March 2017).

Richardson D and Monro S (2012) Sexuality, Equality \& Diversity, Basingstoke: Palgrave 
Macmillan.

Saha S, Beach MC and Cooper LA (2008) Patient centeredness, cultural competence and healthcare quality. Journal of the National Medical Association 100(11): 1275-1285.

Sharpe AN (2010) Foucault's Monsters and the Challenge of Law London: Routledge.

Spade, D. (2003). Resisting medicine, re/modeling gender. Berkeley Women's Law Journal, 18, $15-37$.

Stone S (1991) The empire strikes back: A posttranssexual manifesto. In: Epstein J and Straub

K (eds) Body Guards: The Cultural Politics of Gender Ambiguity. New York: Routledge, pp.280-304.

Stryker S. (1994) My words to Victor Frankenstein above the village of Chamounix -

Performing transgender rage. GLQ: A Journal of Lesbian and Gay Studies 1(3): 227-254.

Suess A (2010) Análisis del panorama discursivo alrededor de la despatologización trans:

Procesos de transformación de los marcos interpretativos en diferentes campos sociales.

In: Missé M and Coll-Planas G (eds) El género desordenado. Críticas en torno a la patologización de la transexualidad. Barcelona: Egales, pp.29-54.

Suess Schwend A (2016) 'Transitar por los géneros es un derecho': Recorridos por la perspectiva de despatologización. PhD Thesis. Granada: University of Granada. Available at: http://hdl.handle.net/10481/42255 (accessed 1 October 2016).

Suess Schwend A (2017). Gender Diversity in Childhood: A Human Right. Archives of Sexual Behavior [online first]. doi:10.1007/s10508-017-0938-0

Suess A, Espineira K and Walters PC (2014) Depathologization. TSQ: Transgender Studies Quarterly 1(1-2): 73-77.

Szasz TS (2009) Antipsychiatry: Quakery Squared, Syracuse NY: Syracuse University Press.

Sørlie A (forthcoming 2016) Rettighetssubjekter i endring: Den fødende mannen In Ikdahl I and Blaker Strand V (eds) Rettigheter i velferdsstaten: Begreper, trender, teorier. Oslo: Gyldendal.

TGEU, Transgender Europe and Balzer, Carsten (2016a) Legal Gender Recognition: Change of gender. Sterilisation/SRS/GRS requirement. Available at: https://goo.gl/HixaHK (accessed 22 June 2017)

TGEU, Transgender Europe and Balzer, Carsten (2016a) Legal Gender Recognition: Change of gender. Pathologization requirement. Available at: https://goo.gl/TWPD1R (accessed 22 June 2017)

Theilen JT (2014) Depathologisation of transgenderism and international human rights law. Human Rights Law Review 14(2): 327-342.

Thomas M-Y, Espineira K, and Arnaud A (2013) Transidentités: Histoire d'une dépathologisation. Paris: L'Harmattan. 
Tom Waddell Health Center (2011) Protocols for Hormonal Reassignment of Gender. Available at: http://www.twtransgenderclinic.org/wp/wp-content/uploads/2012/06/TG-protocols2011-revision.pdf (accessed 18 March 2017).

van Kück v. Germany, the European Court of Human Rights, judgment (Chamber), app. no. 35968/97, 12 June 2003.

Whittle S (2002) Respect and Equality: Transsexual and Transgender Rights, London: Cavendish.

Wilchins RA (1997) Gender identity disorder diagnosis harms transsexuals. Transgender Tapestry 79(31):44-45.

Wilson KK (1997) Gender as illness: Issues of psychiatric classification. In: Paul E (ed) Taking Sides - Clashing Views on Controversial Issues in Sex and Gender. Guilford: McGrawHill, pp.31-38.

Wilson KK (2010) The Disparate Classification Of Gender And Sexual Orientation In American Psychiatry. Available at: http://www.priory.com/psych/disparat.htm (accessed 9 February 2016)

Winter S (2009) Cultural considerations for the World Professional Association for Transgender Health's Standards of Care: The Asian perspective. International Journal of Transgenderism 11(1): 19-41.

Winter S (2014) Gender troubles: What's wrong with the WHO proposal for gender incongruence in childhood. Available at: http://www.gidreform.files.wordpress.com/2014/07/20140717samwintergicd.pdf (accessed 9 February 2016).

Winter S (2015) Enhancing lives by depathologizing trans. Available at: http://transactivists.org/2015/10/23/sam-winter-enhancing-lives-by-depathologizingtrans/ (accessed 9 February).

Winter S, Chalungsooth P, Teh YK, et al. (2009) Transpeople, transprejudice and pathologization: A seven-country factor analytic study. International Journal of Sexual Health 21(2): 96-118.

Winter S, Diamond M, Green J, Karasic D, Reed T, Whittle S and Wylie K (2016) Transgender people: health at the margins of society. The Lancet 388(10042):390-400.

Winter S, Ehrensaft D, Pickstone-Taylor S, De Cuypere G and Tando D (2016) The psychomedical case against a gender incongruence of childhood diagnosis. Lancet Psychiatry 3(5):404-405.

Winter S, Riley E, Pickstone-Taylor S, Suess A, Winters K, Griffins L, et al. (2016) The "Gender Incongruence of Childhood" diagnosis revisited: A statement from clinicians and researchers, May 7, 2016. Available at: gicrevisited.org (accessed 1 October 2016). 
Winter S, Settle E, Wylie K, Reisner S, Cabral M, Knudson G and Baral S (2016) Synergies in health and human rights: a call to action to improve transgender health. The Lancet 388(10042):318-321.

Winters K (2006) Gender dissonance: Diagnostic reform of gender identity disorder for adults. Journal of Psychology \& Human Sexuality 17(3-4): 71-89.

Winters K (2008) Gender Madness in American Psychiatry. Essays form the Struggle for Dignity, Dillon, Col: GID Reform Advocates.

Winters K (2013) GID reform in the DSM-5 and ICD-11: A status update. Available at: https://gidreform.wordpress.com/category/dsm-5-2/ (accessed 9 February 2016).

Winters K (2014) Methodological Questions in Childhood Gender Identity 'Desistence' Research. In: 23rd World Professional Association for Transgender Health Biennial Symposium. Bangkok, Thailand, 14-18 February.

WHO (2017a) ICD-11 Phase 1. Available at: https://goo.gl/n7sY66 (accessed 22 June 2017)

WHO (2017b) ICD-11 Beta Draft. Available at:

http://apps.who.int/classifications/icd11/browse/l-m/en (accessed 22 June 2017).

WHO-WPRO (2016). What is people-centered health care? Available at: http://www.wpro.who.int/health_services/people_at_the_centre_of_care/definition/en/ (accessed 9 February 2016).

WPATH (2012) Standards of care for the health of transsexual, transgender, and gender nonconforming people. Available at: http://www.wpath.org/documents/SOC\%20V7\%2003-17-12.pdf (accessed 9 February 2016).

Zowie Davy PhD is a Senior Lecturer in the Centre for LGBTQ Research at De Montfort University, Leicester, England. Zowie's work centers on transgender embodiment, the depathologisation of transgender people, and the sociology of diagnosis. Her most recent publications are entitled: The DSM 5 and the politics of diagnosing transpeople published in Archives of Sexual Behavior (2015) and Facilitating LGBT Medical, Health and Social Care Content in Higher Education Teaching published in Qualitative Research in Education (2015).

Address: Centre for LGBTQ Research, De Montfort University, Leicester, UK, LE1 9BH

Email: zowie.davy@dmu.ac.uk

Anniken Sørlie is a PhD Candidate in the Department of Public and International Law, Faculty of Law at the University of Oslo. Anniken is involved in the research project 'Gender identity and sexual orientation in international and national (Norwegian) law' funded by the Research Council of Norway. Anniken graduated from Law at the University of Oslo in 2012 and holds a 
Bachelor in European and American Studies. Her PhD critically reflects on laws and regulations that impact on the lives of trans* people in Norway.

Amets Suess Schwend qualifications: PhD Social Anthropology, MA Arts Therapies, BA Sociology. Her professional activity is in research and teaching at the Andalusian School of Public Health, Granada, Spain. She has publications on trans depathologisation, gender diversity, human rights, social determinants of health, economic crisis and health, migration, research epistemology, methodology and ethics; she is a member of the coordination team of STP, International Campaign Stop Trans Pathologization, member of the International Expert Group coordinated by GATE, Global Action for Trans* Equality, as well as member of TGEU, Transgender Europe and WPATH, World Professional Association for Transgender Health. 